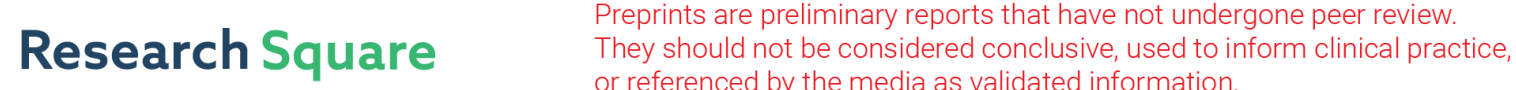 \\ Cointegration Analysis and Forecasting of the Export Function of Bangladesh Using the Error Correction Model
}

K M Saemon Islam ( $\sim$ saemoninc@gmail.com )

Bangladesh Bank https://orcid.org/0000-0002-7093-3514

Gautam Kumar Biswas

Bangladesh Bank

\section{Research}

Keywords: Export function, International trade, Cointegration, Error Correction Model

Posted Date: September 8th, 2020

DOI: https://doi.org/10.21203/rs.3.rs-70018/v1

License: (c) (1) This work is licensed under a Creative Commons Attribution 4.0 International License.

Read Full License 


\title{
Cointegration Analysis and Forecasting of the Export Function of Bangladesh Using the Error Correction Model
}

\author{
Gautam Kumar Biswas \\ Deputy Director, Sustainable Finance Department, Bangladesh Bank (the Central Bank of Bangladesh)
}

K M Saemon Islam

Deputy Director, Debt Management Department, Bangladesh Bank (the Central Bank of Bangladesh)

\begin{abstract}
In this paper, we examined the relationship between the growth of the Gross Domestic Product of the United States, the export value index, and the export of Bangladesh over 37 years between 1980 and 2016. The results of our preliminary tests showed that there was indeed a long-run relationship between these variables. Based on our preliminary analysis, we employed an error-correction model to identify the relationship between the variables. The error-correction term with the expected negative sign was statistically significant, and it confirmed that in the case of disequilibrium, the convergence towards the equilibrium happened in the subsequent periods. Additionally, the econometric estimates exhibited that the two-period lagged values of the growth in export of Bangladesh and the growth of the Gross Domestic Product of the United States were also statistically significant.
\end{abstract}

Keywords: Export function, International trade, Cointegration, Error Correction Model.

JEL Classification: C22, C5, F41.

\section{Introduction}

Export is one of the major indicators of international trade for a country. As suggested by Altintas and Türker (2014), different countries have been focusing on regional trade integrations since the 1950s. Understandably, for trade balance as well as the accumulation of foreign exchange, export plays a crucial role. For a developing country like Bangladesh, the aggregate value of export is arguably even more significant. Ahmed et al. (1993) investigated the aggregate export-demand function of Bangladesh and found price and income to be inelastic. Numerous other studies have also focused on the export functions of different countries to identify the potential roles of other macroeconomic variables. As suggested by Balassa et al. (1989), the responsiveness of exports to different variables has been deemed to be fundamental in evaluating how effective were the policy measures.

In this paper, we aim to develop a small macro-econometric model for the aggregate export-growth function of Bangladesh. The following sections of this study are as follows: Section 2 of this study reviews the existing econometric pieces of literature to identify and observe the contribution of different macroeconomic variables on export. Section 3 specifies the econometric model of this study, and Section 4 describes the source and outline of the data. The following section 5 focuses on the empirical analysis and the evaluation of the results. Section 6 of this paper provides us the diagnostic assessments of the econometric model employed. Section 7 illustrates the impact of different components and forecasts the growth of the export of Bangladesh over the following periods, whereas section 8 provides the concluding remarks based on the findings.

\section{Review of Existing Empirical Works of Literature}

As discussed above, export is considered one of the major determinants for the economic growth of a country, especially for developing countries. Over the past few decades, several studies have been conducted to estimate the export function of different countries around the world. ${ }^{1}$ In this section, we review some of the empirical literature on the export demand function.

Using cointegration analysis and multivariate Granger causation analysis, Altintas and Türker (2014) estimated the import and export functions of Turkey. In their export model, they found the existence of a one-way short-term Granger-causal link from foreign income, real exchange rate and export price

\footnotetext{
${ }^{1}$ See, for example, Murad, S. M. Woahid (2012), Balassa, B., Voloudakis, E., Fylaktos, P., \& Suh, S. T. (1989), Haider, J., Afzal, M. \& Riaz, F. (2011), Kabir, R (1988), Dutta, D. and Ahmed, N. (2004) and Islam, T. (2016).
} 
towards export and foreign income, foreign direct investment, real exchange rates, and the export price are the Granger causes of export in the long run. In contrast, in the import model, they showed that there exists a Granger-causality link from Turkey's real GDP, foreign direct investment, and real exchange rate towards import in the long run. Additionally, single way causality links have been observed from foreign direct investment, real exchange rate, and import price to import.

Sandu and Ghiba (2011) analyzed the effect of the exchange rate on export volumes of Romania. By employing Vector Autoregressive Model (VAR), they found that exports of Romania have a negative relationship with the first lag of the exchange rate, and it is statistically significant, and in their study, they used quarterly data between 2003Q2 -2011Q1. Using the annual data from 1970 to 2006, Khattak and Hussain (2010) estimated the determinants of exports of Pakistan. In their study, they used the Johansen Cointegration test to find the long-term relationship among total exports, primary commodities exports, semi-manufacturers, and exports of manufactured goods. Furthermore, using Ordinary Least Squares (OLS), they found that an increase in primary commodities exports, semimanufacturers, and exports of manufactured goods caused an increase in total export volume in Pakistan.

On the other hand, Cheung and Sengupta (2013) conducted a study to examine the effects of the Real Effective Exchange Rate (REER) on specific types of exports instead of total exports. Using data from 2000 to 2010, they determined the effects of the REER on the share of exports of Indian non-financial sector firms. They revealed that firms with small export shares are more affected by the real effective exchange rate fluctuations. In contrast, Sarker (2018) attempted to estimate the import and export demand functions of Bangladesh on a bilateral basis. In his study, he used the Johansen cointegration test approach and vector error correction mechanism, and he found that income is an important determinant of both import and export demand of Bangladesh, whereas price was a less important factor for both export and import demand of Bangladesh.

\section{Model Specification of the Growth of Export in Bangladesh}

In this section, we focus on developing the econometric specification to model the growth of the export of Bangladesh. Based on the existing empirical literature we reviewed, we understood that several macroeconomic indicators (e.g., foreign GDP, export value index, trade openness, etc.) might have a crucial role to play on the export function of Bangladesh.

According to Houthakker and Magee (1969), trading partner's income is another dominant factor to influence the volume of export to the trading partner. Since the 1980s, the United States (US) has been the predominant export partner of Bangladesh. ${ }^{2}$ So, we have considered the US GDP as one of the major determinants of exports in our model. In contrast, the conventional demand theory says that the consumer is postulated to maximize utility subject to a budget constraint. In this respect, the export demand function is also contingent on the price of exports. In our study, we use the export value index as a proxy of export price.

Therefore, in our estimation, we focus on integrating the growth of US GDP with the export function of Bangladesh. Furthermore, the value of export in proportion to the base period in US Dollar (i.e., the export value index) could be an important variable too in understanding the relationship between the export function of Bangladesh and the growth of US GDP. Therefore, in our study, the export-growth function of Bangladesh is specified as a function of the US GDP and export value index.

Considering the aforementioned factors, the model that we will be focusing on is the following:

$$
\text { l_export }{ }_{t}=\alpha_{0}+\alpha_{1} * \text { l_usgdp } p_{t}+\alpha_{2} * l_{-} \text {xvi } i_{t}+\mu_{t}
$$

Where, for the period $t$,

l_export $=\log$ of export

l_usgdp $=\log$ of US GDP

$l \_x v i=\log$ of export value index and

$\mu=$ error term.

${ }^{2}$ See:https://wits.worldbank.org/CountryProfile/en/Country/BGD/StartYear/1989/EndYear/2015/TradeFlow/Export/Partner/B Y-COUNTRY/Indicator/XPRT-PRTNR-SHR\# 


\section{Data and Software}

For estimating the export function of Bangladesh, we obtain the annual data of the export of Bangladesh expressed in constant LCU from the International Monetary Fund's (IMF) various issues of International Financial Statistics (IFS). We also collect data on the export value index of Bangladesh and gross domestic product (GDP) of the US from 1980 to 2016 from the World Bank's data bank. As a statistical package, we use Gretl to perform all statistical and graphical operations. The details of the tests are available as appendices.

\subsection{Summary Statistics of Data}

The summary of the data related to $l_{-}$export, $l_{-} u s g d p$ and $l_{-} x v i$ is shown in the table-1. The table shows their means, standard deviation (SD), Coefficient of Variation (CV), skewness, and excess Kurtosis.

\begin{tabular}{|c|c|c|c|}
\hline \multicolumn{4}{|c|}{ Table-1: Summary Statistics, using the observations 1980-2016 } \\
\hline \multirow{2}{*}{ Particulars } & \multicolumn{3}{|c|}{ Variable } \\
\cline { 2 - 4 } & l_export & l_usgdp & l_xvi \\
\hline Mean & 12.39 & 15.956 & 4.3316 \\
\hline Median & 12.537 & 16.02 & 4.3964 \\
\hline Minimum & 9.2769 & 14.865 & 2.6711 \\
\hline Maximum & 14.899 & 16.745 & 6.1512 \\
\hline Standard Deviation (SD) & 1.6668 & 0.55735 & 1.113 \\
\hline Coefficient of Variation (CV) & 0.13453 & 0.03493 & 0.25694 \\
\hline Skewness & -0.1004 & -0.327 & 0.04769 \\
\hline Excess Kurtosis & -1.1827 & -1.0873 & -1.2773 \\
\hline
\end{tabular}

\subsection{Time-Series Plot}

The time-series plotting of $l_{-}$export, $l_{-} u s g d p$ and $l_{-} x v i$ is displayed in the Figure-1 below:

1_export, 1_usgdp and 1_xvi (1980-2016)

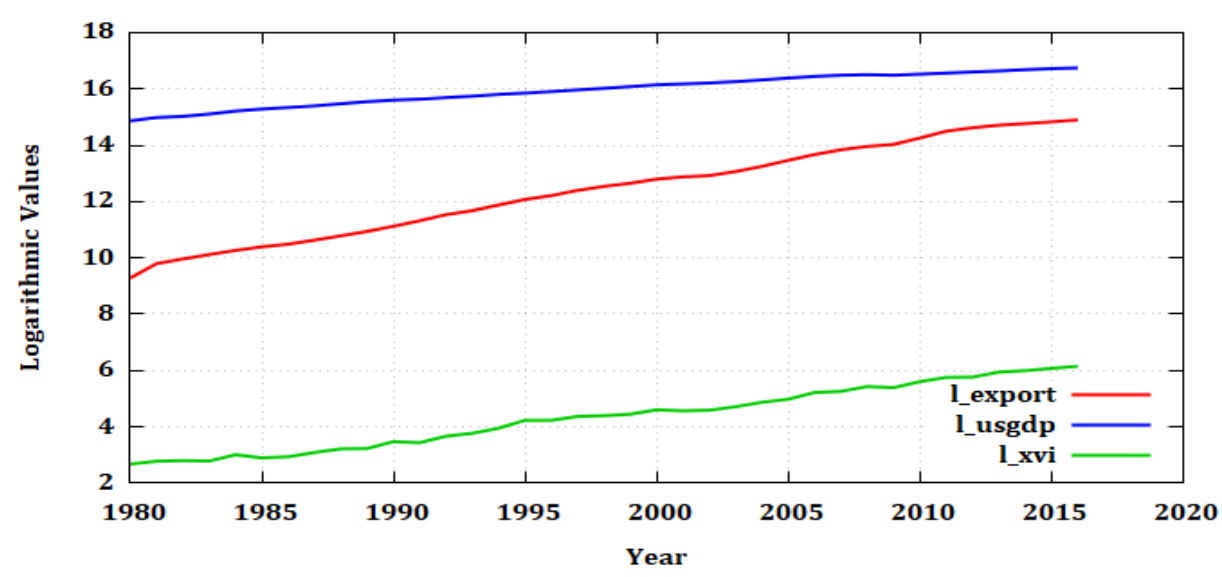

Figure-1: Graphical Plotting of l_export, l_usgdp, and l_xvi

The initial eye-balling of the graph indicates a probable non-stationarity suggesting the variables may contain a trend.

\section{Empirical Analysis}

\subsection{Stationarity Checking}

Although eye-balling indicated a probable non-stationarity among the variables, to formally check for the stationarity, in this section, we analyze the data by plotting the correlograms on levels and by performing Augmented Dickey-Fuller tests both on levels and first differences of $l_{-}$export, $l_{-} u s g d p$, and $l \_x v i$. 


\subsubsection{Correlogram}

The Figure-2 below shows the Autocorrelation Function (ACF) and Partial Autocorrelation Function (PACF) of the three variables:
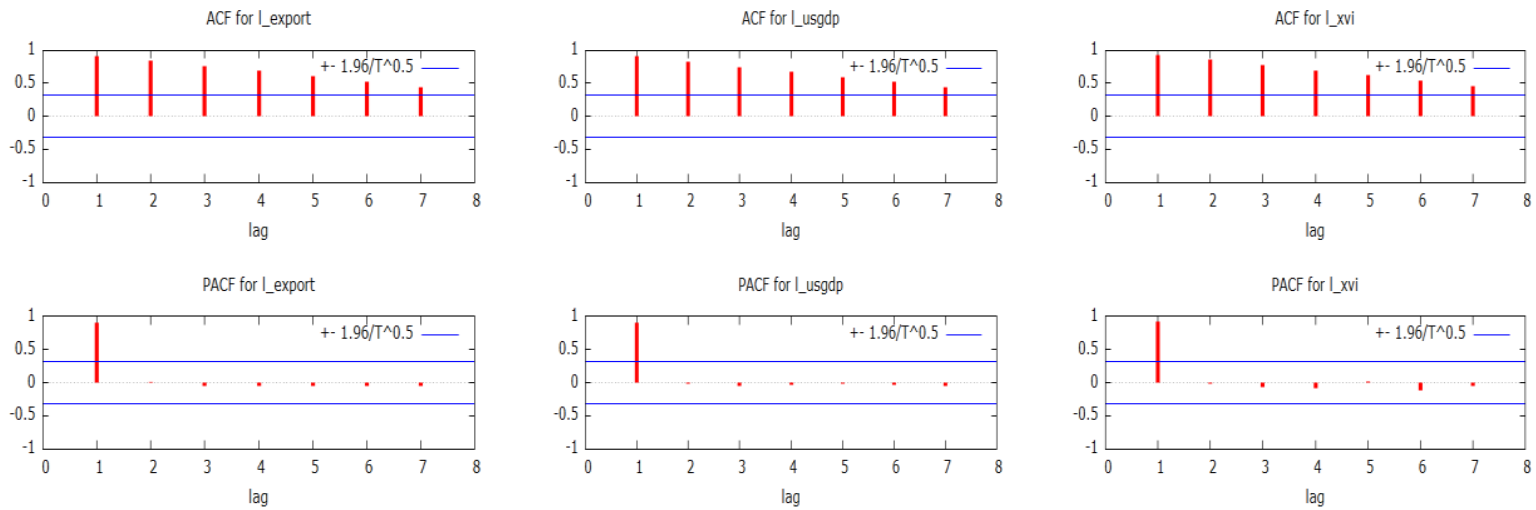

Figure-2: Correlograms of l_export, $l \_u s g d p$ and l_xvi

From Figure-2, for all three of the variables, it becomes clear that the ACFs do not die down and significant at $5 \%$ levels for all of them. Therefore, the inspections of the correlograms also point to a non-stationarity.

\subsubsection{Unit-root test}

At this stage, we employ the Augmented Dickey-Fuller (ADF) to check for the non-stationarity of variables. The Table- 2 below shows the ADF tests both on levels and first differences of l_export, l_usgdp, and $l \_x v i$ and the conclusions:

\begin{tabular}{|c|c|c|c|c|}
\hline \multicolumn{5}{|c|}{ Table-2: Augmented Dickey-Fuller (ADF) test for l_export,, _usgdp and l_xvi } \\
\hline Variable & Parameter & ADF Statistics & Asymptotic P-Value & Decision \\
\hline \multirow{2}{*}{ l_export } & Level & -1.05673 & 0.9345 & \multirow{2}{*}{$\mathrm{I}(1)$} \\
\hline & First diff. & -7.22703 & $5.422 \mathrm{e}-007$ & \\
\hline \multirow{2}{*}{ l_usgdp } & Level & -2.03729 & 0.5802 & \multirow{2}{*}{$\mathrm{I}(1)$} \\
\hline & First diff. & -4.17009 & 0.002471 & \\
\hline \multirow{2}{*}{ l_xvi } & Level & -2.99321 & 0.134 & \multirow{2}{*}{$\mathrm{I}(1)$} \\
\hline & First diff. & -8.69248 & $2.321 \mathrm{e}-008$ & \\
\hline \multicolumn{5}{|c|}{$H_{0}:$ the variable has a unit roo } \\
\hline & & & Testing down from & terion $A I$ \\
\hline
\end{tabular}

The ADF tests confirm that all three variables are non-stationary at levels but stationary at first differences. Therefore, the test confirms that all the variables are integrated at the order one [I(1)].

\subsection{Collinearity Checking}

To inspect for the probable collinearity between the first differences of the variables, we perform a collinearity checking. The results of the Belsley-Kuh-Welsch test are stated below in the Table-3:

\begin{tabular}{|c|c|c|c|c|c|}
\hline \multicolumn{7}{|c|}{ Table-3: Belsley-Kuh-Welsch Collinearity Diagnostics } \\
\hline lambda & cond & Const & d_1_export & d_1_usgdp & d_1_xvi \\
\hline 3.450 & 1.000 & 0.011 & 0.010 & 0.009 & 0.026 \\
\hline 0.367 & 3.064 & 0.028 & 0.013 & 0.032 & 0.938 \\
\hline 0.108 & 5.663 & 0.696 & 0.573 & 0.006 & 0.008 \\
\hline 0.075 & 6.777 & 0.265 & 0.403 & 0.953 & 0.027 \\
\hline
\end{tabular}

As the conditions (cond) are less than 10, the results show that there is no evidence of excessive collinearity between them. 


\subsection{Vector Autoregression (VAR) Lag-Length Selection}

Before performing a VAR model (and a probable VAR with error correction), we perform the operations to calculate different information criteria to identify the suitable lag(s) for our models. Table4 below summarizes the data of the calculation:

\begin{tabular}{|c|c|c|c|}
\hline \multicolumn{4}{|c|}{ Table-4: Calculation of Information Criteria for VAR Lag Selection } \\
\hline lags & AIC & BIC & HQC \\
\hline 1 & -11.018092 & $-10.473907^{*}$ & -10.834990 \\
\hline 2 & -11.376456 & -10.424133 & -11.056028 \\
\hline 3 & 11.327490 & -9.967029 & -10.869736 \\
\hline 4 & $-11.836434^{*}$ & -10.067834 & $-11.241354^{*}$ \\
\hline
\end{tabular}

Based on the Akaike Information Criterion (AIC), the lag-length (p) of a VAR analysis should be 4 (indicated by the asterisk) as it minimizes the AIC value. Therefore, for the Johansen cointegration test, the lag-length of (p-1) or 3 seems like a rational selection.

\subsection{Cointegration Tests}

Before the selection of the model, we need to check the variables for cointegration, i.e., if there exists a stationary long-run relationship concerning their movements from each other. To check for cointegration, in this section, we employ the Engle-Granger test and the Johansen test.

\subsubsection{Engle-Granger Test}

Based on Engle and Granger (1987), in this section, we check for the stationarity of the residuals. The summary of the Engle-Granger test is stated below:

\begin{tabular}{|l|l|}
\hline \multicolumn{2}{|c|}{ Table-5: Engle-Granger Test for Cointegration } \\
\hline Unit-root $H_{0}: a=1$ & Estimated value of $(\mathrm{a}-1):-0.673247$ \\
Model: $(1-\mathrm{L}) \mathrm{y}=(\mathrm{a}-1){ }^{*} \mathrm{y}(-1)+\mathrm{e}$ & Test statistic: tau_c $(3)=-5.02535$ \\
& The $\mathrm{p}$-value 0.004799 \\
\hline
\end{tabular}

Here, the p-value $<0.05$, therefore the Engle-Granger test rejects the null hypothesis at a $5 \%$ significance level. This means, there is at least 1 (one) cointegrating relationship between the variables.

\subsubsection{Johansen Cointegration Test}

Based on Johansen (1988), in this section, we conduct the cointegration test. As stated above, for the Johansen cointegration test, the lag-length of three would be our selection. Now, corrected for sample size, the details of the trace test and eigenvalue test are shown below:

\begin{tabular}{|c|c|c|c|c|}
\hline \multicolumn{5}{|c|}{ Table-5: Johansen Cointegration Test } \\
\hline \multirow{2}{*}{ Rank } & \multicolumn{2}{|c|}{ Trace Test } & \multicolumn{2}{c|}{$\lambda_{\max }$ Test } \\
\cline { 2 - 5 } & Test stat & p-value & Test stat & p-value \\
\hline 0 & 34.157 & 0.0307 & 18.181 & 0.1263 \\
\hline 1 & 15.976 & 0.0549 & 9.3699 & 0.2624 \\
\hline 2 & 6.6059 & 0.0152 & 6.6059 & 0.0102 \\
\hline
\end{tabular}

As per the standard practice, the trace test outcomes take precedence over the $\lambda_{\max }$ (eigenvalue) test. So, at 5\% significance level, we reject the $H_{0}$ : Rank 0 , which means that there exists one long-run relationship between the variables. The long-run relationship under there parameters is denoted by the following equation (derived from the renormalized vector):

$$
\text { l_export }=0.94687 \times \text { l_usgdp }+0.91169 \times l \_x v i
$$




\subsection{Vector Error Correction Model (VECM)}

As the variables $l_{-}$export, $l_{-} u s g d p$ and $l_{\_} x v i$ show the presence of a cointegration relationship between them, we need to formulate our model incorporating an error-correction term into it. Theoretically, the model now becomes,

$$
\Delta l_{-} \exp =\alpha_{0}+\sum_{1}^{n} \alpha_{1 i} \Delta l_{-} \exp _{t-i}+\sum_{1}^{n} \alpha_{2 i} \Delta l_{-} u s g d p_{t-i}+\sum_{1}^{n} \alpha_{3 i} \Delta l_{-} x v i_{t-i}+\alpha_{4} E C_{t-1}+\mu_{t}
$$

Where, $E C_{t-1}=$ the error correction term lagged one period.

The results of the VECM is shown below:

\begin{tabular}{|c|c|c|c|c|c|}
\hline \multicolumn{6}{|c|}{ Table-6: $\Delta l \_e x p$} \\
\hline Variables & Coefficient & Std. Error & t-ratio & p-value & Significance \\
\hline$\alpha_{0}$ & -1.90493 & 0.616359 & -3.091 & 0.0047 & $* * *$ \\
\hline$\Delta l \_\exp _{t-1}$ & 0.684124 & 0.211369 & 3.237 & 0.0033 & $* * *$ \\
\hline$\Delta l_{-} \exp _{t-2}$ & -0.0330907 & 0.133698 & -0.2475 & 0.8065 & \\
\hline$\Delta l \_u s g d p_{t-1}$ & -0.701877 & 0.500416 & -1.403 & 0.1726 & \\
\hline$\Delta l \_u s g d p_{t-2}$ & -1.25386 & 0.569316 & -2.202 & 0.0367 & $* *$ \\
\hline$\Delta l_{-} x v i_{t-1}$ & -0.208487 & 0.101467 & -2.055 & 0.0501 & $*$ \\
\hline$\Delta l_{-} x v i_{t-1}$ & 0.0120836 & 0.0920498 & 0.1313 & 0.8966 & \\
\hline$E C_{t-1}$ & -0.312381 & 0.0961600 & -3.249 & 0.0032 & $* * *$ \\
\hline
\end{tabular}

The statistical measures of this model are stated below:

\begin{tabular}{|l|r|l|r|}
\hline \multicolumn{4}{|c|}{ Table-7: Statistical Measures of the Model } \\
\hline Mean of Dependent Variable & 0.145301 & SD of Dependent Variable & 0.052875 \\
\hline Sum of Squared Residuals & 0.044214 & SE of Regression & 0.041237 \\
\hline R-squared Value & 0.520766 & Adjusted R-squared value & 0.391742 \\
\hline Rho & -0.006499 & Durbin-Watson Value & 2.005787 \\
\hline
\end{tabular}

The results from the model (in Table-6) show that the error-correction term $E C_{t-1}$ is statistically highly significant (even at a $1 \%$ significance level), and expectedly it has a negative sign. This points to the soundness of our equation (1), indicating that between the variable, there is indeed a long-term equilibrium relationship. The coefficient of $E C_{t-1}(-0.312381)$ shows that in case of a deviation, the variables converge to the equilibrium by adjusting the preceding period's disequilibrium at over $31 \%$ in the following period.

Furthermore, the intercept, $\Delta l_{-} \exp _{t-1}$ and $\Delta l_{-} u s g d p_{t-2}$ are significant at a 5\% significance level. In contrast, $\Delta l_{-} x v i_{t-1}$ is significant at a $10 \%$ significant level. Concerning the coefficients, the elasticity of the two-period lagged value of the change in the growth of the US GDP is more than unit-elastic (1.25386). However, although it is less than unity (0.684124), the sign is positive for the one-period lagged value of the change in the growth of the export (as we would expect from the economic standpoint) indicating that the current period's value increases at a lesser rate.

From Table-7, we see that the R-squared and the adjusted R-squared values are 0.520766 and 0.391742 , respectively. Furthermore, the Rho of -0.006499 and the Durbin-Watson (DW) value of around 2 indicates the presence of an insignificant autocorrelation in the model. 


\section{Diagnostic Tests}

Although the initial diagnostics (stated above) show no apparent misspecification with very little sign of autocorrelation in our model (with the DW stat of 2.005787), we perform additional diagnostic tests to check for probable conditional heteroskedasticity and non-normality.

\subsection{Autoregressive Conditional Heteroskedasticity (ARCH) Test:}

To check for the probable conditional heteroskedasticity in our model, we conduct the test for the presence of $\mathrm{ARCH}$. The results of the ARCH test is stated in the table below:

\begin{tabular}{|c|c|c|c|}
\hline \multicolumn{5}{|c|}{ Table-8: Results of the ARCH Test } \\
\hline Lag & LM & df & p-value \\
\hline 1 & 47.057 & 36 & 0.1027 \\
\hline 2 & 81.559 & 72 & 0.2064 \\
\hline 3 & 119.110 & 108 & 0.2187 \\
\hline
\end{tabular}

The test results from the Table- 8 show that the ARCH test fails to reject the null hypothesis $\left(H_{0}\right.$ : No conditional heteroscedasticity) at a $5 \%$ significance level. Thus, the test confirms that there is no problem with conditional heteroscedasticity in our model.

\subsection{Normality Test}

The test to check for the normality in the model is crucial, as it would ensure the forecasting-ability of our model. To check for a probable non-normality, we perform the Doornik-Hansen test. The results of the test are stated below:

\begin{tabular}{|c|c|}
\hline \multicolumn{2}{|c|}{ Table-9: Results of the Doornik-Hansen Test } \\
\hline Test Stat & p-value \\
\hline Chi-square(6) $=7.67642$ & 0.2628 \\
\hline
\end{tabular}

The test result from the Table-9 states that the Doornik-Hansen test fails to reject the null hypothesis at a $5 \%$ significance level. Therefore, the test confirms that the residuals are normally distributed.

\section{Forecasting}

In this section, we focus on the variance decomposition of the forecast, the impulse responses to innovations, and the forecasting of $l_{-}$export over the periods following our study.

\subsection{Decomposition of Variance}

As we know, the variance decomposition of forecasting measures how each type of shock impacts the error variance of the forecast. The Table-10 below shows the variance decomposition of $l_{-}$export:

\begin{tabular}{|c|c|c|c|c|}
\hline \multicolumn{5}{|c|}{ Table-10: Variance Decomposition for l_export } \\
\hline Period & Standard Error & l_export & l_usgdp & l_xvi \\
\hline 1 & 0.036061 & 100.0000 & 0.0000 & 0.0000 \\
\hline 2 & 0.0625141 & 98.8653 & 0.6535 & 0.4812 \\
\hline 3 & 0.0863231 & 87.4304 & 6.8454 & 5.7242 \\
\hline 4 & 0.109012 & 75.4082 & 13.0470 & 11.5449 \\
\hline 5 & 0.126999 & 68.0547 & 15.2993 & 16.6459 \\
\hline 6 & 0.139833 & 64.1491 & 15.0935 & 20.7574 \\
\hline 7 & 0.14957 & 61.9289 & 13.9987 & 24.0724 \\
\hline 8 & 0.157964 & 60.5371 & 12.7519 & 26.7110 \\
\hline 9 & 0.166016 & 59.4897 & 11.5903 & 28.9200 \\
\hline 10 & 0.174118 & 58.5210 & 10.5523 & 30.9267 \\
\hline
\end{tabular}


The following Figure-3 graphically represents the variance decomposition of the forecast for $l_{-}$export:

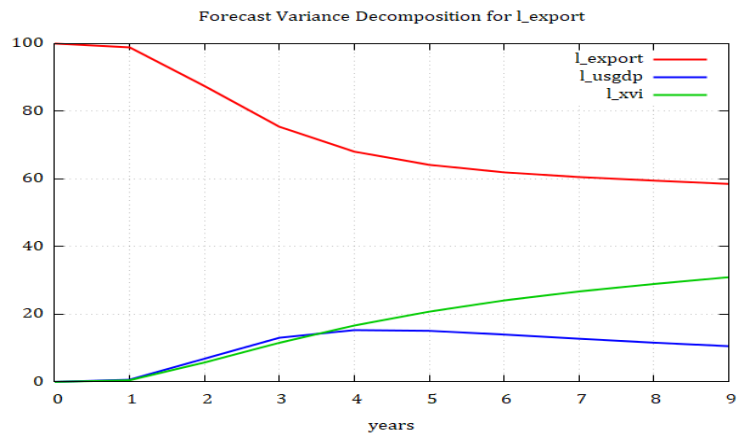

Figure-3: Forecast of Variance Decomposition for l_export

As illustrated by Table-10 and Figure-3, although initially higher, the innovation in the growth of the US GDP has a lesser effect comparing to the growth of the export value index in the long run.

\subsection{Impulse Response Functions}

To check for the impact of a one standard deviation shock to the model, we check for the impulse response functions. The responses are graphically shown in the figure below:
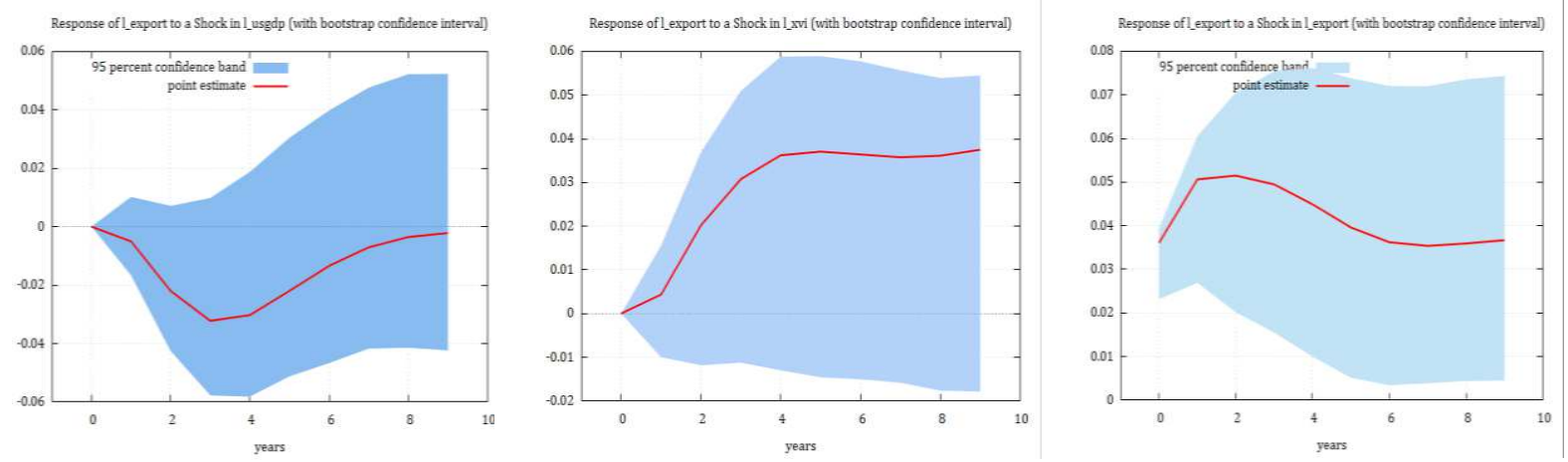

Figure-4: Impulse Response Functions of l_export (with 95\% Confidence Band)

As it is evident from the Figure-4, the impacts on $l_{-}$export to a shock to $l_{-} u s g d p$ and $l_{-}$export are of a short-run nature. In contrast, a shock to $l_{-} x v i$ has a longer-term impact on $l_{-}$export. In contrast, the response of $l_{-}$export to a shock to $l_{-} u s g d p$ is negative, unlike the other two.

\section{3. $\quad$ Forecasting of the Growth in Export}

As our model passed our diagnostic tests, in this section, we forecast the growth in export for the subsequent five periods (2017-2021). The representation below in the Figure-4 includes the fitted values for the pre-forecast range to illustrate the fit of our model graphically.

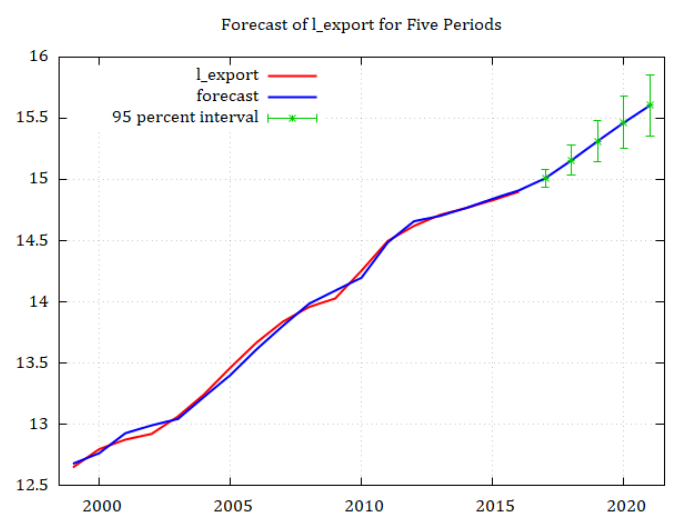

Figure-4: Forecast of l_export (Including Fitted Values for Pre-forecast Range)

As illustrated by Figure-4, our model forecasts a steady increase in the growth of export over the forecasting period of five years subsequent to our analysis period between 1980 and 2016. 


\section{Conclusion}

In this study, we examined the impact of the growth of US GDP and the export value index on the growth of the export of Bangladesh. We focused on the period between 1980 and 2016 in our analysis. As a standard method of dealing with time-series data, we initially focused on identifying a probable non-stationarity of the variables. Apart from the inspection of correlograms, the subsequent ADF tests confirmed the presence of a non-stationarity among all three variables in question. Therefore, before selecting our desired model, we conducted the Engle-Granger test and the Johansen test to observe whether there exists a cointegration between the variables. The empirical analysis showed that there is a long-run relationship between the variables, as evident by the results.

In the presence of a long-run relationship between the variables, we modeled the variables using an error-correction model. After defining the parameters and running the model, we conducted the diagnostic checks that indicated no significant presence of a serial correlation, conditional heteroskedasticity, or non-normality in our model. Following our diagnostic tests, we inspected the impulse response functions and found out that the impacts on the growth of export to a shock to the growth of the US GDP were of a short-run nature, whereas the impact to a shock to the growth of the export value index was a longer-run one. Furthermore, our error-correction rate of over $31 \%$ showed that in the case of disequilibrium in the preceding period, the adjustment to the equilibrium would happen at a significant rate. And, according to our forecast, assuming these existing conditions hold, we would expect the growth rate of the export of Bangladesh to increase at a steady rate over the periods following our study. 


\section{Bibliography}

Ahmed, Syed Mushtaque; Hoque, Md Nazmul; Talukder, Md Sherajul Islam (1993): Estimating Export Demand Function for Bangladesh. An Application of Cointegration and Error-correction Modelling, The Bangladesh Development Studies 21 (4), pp. 89-104.

Altintaş, Halil; Türker, Oğuzhan (2014): The Dynamics of Export and Import Functions in Turkey. Cointegration and Multivariate Granger Causation Analysis, International Journal of Asian Social Science 4 (5), pp. 676-689.

Balassa, Bela; Voloudakis, Evangelos; Fylaktos, Panagiotis; Suh, Suk Tai (1989): The Determinants of Export Supply and Export Demand in Two Developing Countries- Greece and Korea, International Economic Journal 3 (1), pp. 1-16.

Cheung, Yin-Wong; Sengupta, Rajeswari (2013): Impact of Exchange Rate Movements on Exports: An Analysis of Indian Non-Financial Sector Firms, Journal of International Money and Finance 39, pp. 231-245.

Dutta, Dilip; Ahmed, Nasiruddin (2004): An Aggregate Import Demand Function for India: A Cointegration Analysis", Applied Economics Letters, 11:10, 607-613.

Engle, Robert F.; Granger, Clive W. (1987). Co-integration and Error Correction: Representation, Estimation, and Testing, Econometrica: Journal of the Econometric Society, 251-276.

Haider, Jahanzaib; Afzal, Muhammad; Riaz, Farah (2011): Estimation of import and export demand functions using bilateral trade data: The case of Pakistan, BEH-Business and Economic Horizons, Volume 6, Issue 3, pp. 40-53.

Houthakker, Hendrik S.; Magee, Stephen P. (1969): Income and Price Elasticities in World Trade, Review of Economics and Statistics, May, 51(2).

Islam, Touhidul (2016): An Empirical Estimation of Export and Import Demand Functions Using Bilateral Trade Data: The Case of Bangladesh, Journal of Commerce \& Management Thought, 7(3), 526-551.

Johansen, Søren (1988). Statistical Analysis of Cointegrating Vectors, Journal of Economic Dynamics and Control, 12, 231-254.

Kabir, Rezaul (1988): Estimating import-demand and export-demand functions: The case of Bangladesh, Bangladesh Development Studies, 16(4), 115-127.

Khattak, Naeem Ur Rehman; Hussain, Anwar Hussain (2010): Determinants of Exports in Pakistan. An Econometric Analysis (1970-2006), University Library of Munich, Germany.

Murad, S. M. Woahid (2012): Bilateral Export and Import Demand Functions of Bangladesh: A Cointegration Approach, Bangladesh Development Studies, Vol. XXXV, March 2012, No. 1.

Sandu, Carmen; Ghiba, Nicolae (2011): The Relationship between Exchange Rate and Exports in Romania Using a Vector Autoregressive Model, Annales Universitatis Apulensis: Series Oeconomica 13 (2), p. 476.

Sarker, Mohammad Monirul Islam (2018): Export and Import Demand Functions of Bangladesh: A Disaggregated Approach, International Journal of Economics, Finance and Management Sciences 6 (2), p. 66. 


\section{Appendices}

Collinearity Checking

\section{Appendix-A}

Belsley-Kuh-Welsch collinearity diagnostics:

\begin{tabular}{|c|c|c|c|c|c|}
\hline \multicolumn{2}{|c|}{} & \multicolumn{4}{|c|}{ Variance proportions } \\
\hline lambda & cond & const & d_l_export & d_l_usgdp & d_l_xvi \\
\hline 3.450 & 1.000 & 0.011 & 0.010 & 0.009 & 0.026 \\
\hline 0.367 & 3.064 & 0.028 & 0.013 & 0.032 & 0.938 \\
\hline 0.108 & 5.663 & 0.696 & 0.573 & 0.006 & 0.008 \\
\hline 0.075 & 6.777 & 0.265 & 0.403 & 0.953 & 0.027 \\
\hline
\end{tabular}

lambda $=$ eigenvalues of inverse covariance matrix (smallest is 0.0751256 )

cond $=$ condition index

note: variance proportions columns sum to 1.0

According to BKW, cond >= 30 indicates "strong" near-linear dependence, and cond between 10 and 30 "moderately strong". Parameter estimates whose variance is mostly associated with problematic cond values may themselves be considered problematic.

Count of condition indices $>=30: 0$

Count of condition indices $>=10: 0$

Result: No evidence of excessive collinearity

\section{Appendix-B}

\section{VAR Lag-Length Selection}

VAR system, maximum lag order 4:

The asterisks below indicate the best (that is, minimized) values of the respective information criteria.

$\mathrm{AIC}=$ Akaike criterion,

$\mathrm{BIC}=$ Schwarz Bayesian criterion and

$\mathrm{HQC}=$ Hannan-Quinn criterion .

\begin{tabular}{|c|c|c|c|c|c|}
\hline lags & loglik & p(LR) & AIC & BIC & HQC \\
\hline 1 & 193.79852 & - & -11.018092 & $-10.473907^{*}$ & -10.834990 \\
\hline 2 & 208.71153 & 0.00047 & -11.376456 & -10.424133 & -11.056028 \\
\hline 3 & 216.90359 & 0.05928 & 11.327490 & -9.967029 & -10.869736 \\
\hline 4 & 234.30116 & 0.00006 & $-11.836434^{*}$ & -10.067834 & $-11.241354^{*}$ \\
\hline
\end{tabular}


Engle-Granger Test for Integration

\section{Appendix-C}

Step 1: cointegrating regression

Cointegrating regression -

OLS, using observations 1980-2016 $(\mathrm{T}=37)$

Dependent variable: 1_export

coefficient std. error t-ratio p-value

$\begin{array}{lcccc}\text { const } & -13.2355 & 1.95650 & -6.765 & 8.90 \mathrm{e}-08 \\ \text { l_usgdp } & 1.38686 & 0.141488 & 9.802 & 1.94 \mathrm{e}-011 * * * \\ \text { l_xvi } & 0.807377 & 0.0708539 & 11.39 & 3.72 \mathrm{e}-013 * * *\end{array}$

Mean dependent var 12.39008

Sum squared resid $\quad 0.247564$

R-squared $\quad 0.997525$

Log-likelihood 40.12885

Schwarz criterion -69.42496

rho $\quad 0.326753$

Step 2: testing for a unit root in uhat

Augmented Dickey-Fuller test for uhat testing down from 4 lags, criterion AIC

sample size 36

unit-root null hypothesis: $\mathrm{a}=1$

test without constant

including 0 lags of (1-L)uhat

model: $(1-\mathrm{L}) \mathrm{y}=(\mathrm{a}-1) * \mathrm{y}(-1)+\mathrm{e}$

estimated value of $(a-1):-0.673247$

test statistic: tau_c(3) $=-5.02535$

p-value 0.004799

1st-order autocorrelation coeff. for e: 0.146

There is evidence for a cointegrating relationship if:

(a) The unit-root hypothesis is not rejected for the individual variables, and

(b) the unit-root hypothesis is rejected for the residuals (uhat) from the cointegrating regression.
S.D. dependent var 1.666790

S.E. of regression 0.085330

Adjusted R-squared 0.997379

Akaike criterion $\quad-74.25771$

Hannan-Quinn $\quad-72.55394$

Durbin-Watson 1.068633 


\section{Johansen Cointegration Test}

\section{Appendix-D}

Number of equations $=3$

Lag order $=3$

Estimation period: $1983-2016(T=34)$

Case 3: Unrestricted constant

Log-likelihood $=318.372$ (including constant term: 221.884)

Rank Eigenvalue Trace test p-value Lmax test p-value

$\begin{array}{llll}0 & 0.41418 & 34.157[0.0139] & 18.181 \text { [0.1263] }\end{array}$

$\begin{array}{llll}1 & 0.24087 & 15.976[0.0407] & 9.3699[0.2624]\end{array}$

$\begin{array}{llll}2 & 0.17658 & 6.6059[0.0102] & 6.6059[0.0102]\end{array}$

Corrected for sample size $(\mathrm{df}=24)$

Rank Trace test p-value

$0 \quad 34.157[0.0307]$

$1 \quad 15.976[0.0549]$

$26.6059[0.0152]$

$\begin{array}{llll}\text { eigenvalue } & 0.41418 & 0.24087 & 0.17658\end{array}$

beta (cointegrating vectors)

$\begin{array}{lrrr}\text { 1_export } & -13.597 & 1.5495 & -20.569 \\ \text { 1_usgdp } & 12.875 & -17.014 & 17.941 \\ \text { 1_xvi } & 12.396 & 5.6541 & 22.230\end{array}$

alpha (adjustment vectors)

1_export $\quad 0.022974 \quad-0.010382 \quad-0.0043334$

1_usgdp $0.0066546 \quad 0.0030564 \quad-0.0039392$

$\begin{array}{llll}1 \_x v i & 9.9322 \mathrm{e}-005 & -0.021941 & -0.023001\end{array}$

renormalized beta

$\begin{array}{lccl}\text { 1_export } & 1.0000 & -0.091067 & -0.92529 \\ \text { 1_usgdp } & -0.94687 & 1.0000 & 0.80703 \\ \text { 1_xvi } & -0.91169 & -0.33232 & 1.0000\end{array}$

renormalized alpha

$\begin{array}{lclc}\text { 1_export } & -0.31238 & 0.17665 & -0.096334 \\ \text { 1_usgdp } & -0.090482 & -0.052002 & -0.087570 \\ \text { 1_xvi } & -0.0013505 & 0.37331 & -0.51133\end{array}$

long-run matrix (alpha * beta')

1_export 1_usgdp 1_xvi

1_export $-0.23933 \quad 0.394690 .12976$

1_usgdp $\quad-0.0047197 \quad-0.036998 \quad 0.012203$

1_xvi $\quad 0.43778 \quad-0.038071 \quad-0.63416$ 


\section{Appendix-E}

VECM system, lag order 3

Maximum likelihood estimates, observations 1983-2016 ( $\mathrm{T}=34)$

Cointegration rank $=1$

Case 3: Unrestricted constant

beta (cointegrating vectors, standard errors in parentheses)

$$
\begin{array}{cc}
\text { 1_export } & 1.0000 \\
& (0.00000) \\
\text { 1_usgdp-0.94687 } & (0.26794) \\
& \\
\text { 1_xvi } & -0.91169
\end{array}
$$

alpha (adjustment vectors)

$$
\begin{array}{cc}
\text { 1_export } & -0.31238 \\
\text { l_usgdp-0.090482 } & -0913505 \\
\text { 1_xvi } & -0.001350
\end{array}
$$

Log-likelihood $=213.8966$

Determinant of covariance matrix $=6.8899718 \mathrm{e}-010$

$$
\begin{aligned}
\mathrm{AIC} & =-10.8174 \\
\mathrm{BIC} & =-9.4707 \\
\mathrm{HQC} & =-10.3582
\end{aligned}
$$

Equation 1: d_1_export

\begin{tabular}{|l|c|c|c|c|c|}
\hline & Coefficient & Std. Error & t-ratio & $p$-value & \\
\hline const & -1.90493 & 0.616359 & -3.091 & 0.0047 & $* * *$ \\
\hline d_1_export_1 & 0.684124 & 0.211369 & 3.237 & 0.0033 & $* * *$ \\
\hline d_1_export_2 & -0.0330907 & 0.133698 & -0.2475 & 0.8065 & \\
\hline d_1_usgdp_1 & -0.701877 & 0.500416 & -1.403 & 0.1726 & \\
\hline d_1_usgdp_2 & -1.25386 & 0.569316 & -2.202 & 0.0367 & $* *$ \\
\hline d_1_xvi_1 & -0.208487 & 0.101467 & -2.055 & 0.0501 & $*$ \\
\hline d_1_xvi_2 & 0.0120836 & 0.0920498 & 0.1313 & 0.8966 & \\
\hline EC1 & -0.312381 & 0.0961600 & -3.249 & 0.0032 & $* * *$ \\
\hline
\end{tabular}

\begin{tabular}{|l|r|l|l|r|}
\hline Mean dependent var & 0.145301 & & SD dependent var & 0.052875 \\
\hline Sum squared resid & 0.044214 & & SE of regression & 0.041237 \\
\hline R-squared & 0.520766 & & Adjusted R-squared & 0.391742 \\
\hline rho & -0.006499 & & Durbin-Watson & 2.005787 \\
\hline
\end{tabular}

Equation 2: d_1_usgdp

\begin{tabular}{|l|c|c|c|c|c|}
\hline & Coefficient & Std. Error & t-ratio & $p$-value & \\
\hline const & -0.559423 & 0.235158 & -2.379 & 0.0250 & $* *$ \\
\hline d_1_export_1 & 0.00337318 & 0.0806435 & 0.04183 & 0.9670 & \\
\hline d_1_export_2 & 0.106251 & 0.0510097 & 2.083 & 0.0472 & $* *$ \\
\hline d_1_usgdp_1 & 0.612569 & 0.190923 & 3.208 & 0.0035 & $* * *$ \\
\hline d_1_usgdp_2 & -0.542343 & 0.217210 & -2.497 & 0.0192 & $* *$ \\
\hline d_1_xvi_1 & -0.101971 & 0.0387126 & -2.634 & 0.0140 & $* *$ \\
\hline d_1_xvi_2 & -0.0142083 & 0.0351196 & -0.4046 & 0.6891 & \\
\hline EC1 & -0.0904822 & 0.0366878 & -2.466 & 0.0206 & $* *$ \\
\hline
\end{tabular}




\begin{tabular}{|l|l|l|l|r|}
\hline Mean dependent var & 0.050654 & & SD dependent var & 0.021402 \\
\hline Sum squared resid & 0.006436 & & SE of regression & 0.015733 \\
\hline R-squared & 0.574221 & & Adjusted R-squared & 0.459588 \\
\hline rho & 0.026758 & & Durbin-Watson & 1.924665 \\
\hline
\end{tabular}

Equation 3: d_1_xvi

\begin{tabular}{|l|c|c|c|c|c|}
\hline & Coefficient & Std. Error & t-ratio & $p$-value & \\
\hline const & 0.148535 & 1.20797 & 0.1230 & 0.9031 & \\
\hline d_1_export_1 & 0.806810 & 0.414251 & 1.948 & 0.0623 & $*$ \\
\hline d_1_export_2 & -0.164848 & 0.262028 & -0.6291 & 0.5348 & \\
\hline d_1_usgdp_1 & 0.343830 & 0.980736 & 0.3506 & 0.7287 & \\
\hline d_1_usgdp_2 & -1.83494 & 1.11577 & -1.645 & 0.1121 & \\
\hline d_1_xvi_1 & -0.710820 & 0.198860 & -3.574 & 0.0014 & $* * *$ \\
\hline d_1_xvi_2 & -0.0262760 & 0.180403 & -0.1457 & 0.8853 & \\
\hline EC1 & -0.00135048 & 0.188459 & -0.007166 & 0.9943 & \\
\hline
\end{tabular}

\begin{tabular}{|l|r|l|l|r|}
\hline Mean dependent var & 0.098516 & & SD dependent var & 0.097714 \\
\hline Sum squared resid & 0.169824 & & SE of regression & 0.080819 \\
\hline R-squared & 0.461024 & & Adjusted R-squared & 0.315915 \\
\hline rho & 0.154804 & & Durbin-Watson & 1.690158 \\
\hline
\end{tabular}

Cross-equation covariance matrix:

\begin{tabular}{lccc} 
& \multicolumn{2}{c}{ 1_export } & 1_usgdpl_xvi \\
1_export & 0.0013004 & 0.00018117 & 0.0015134 \\
1_usgdp & 0.00018117 & 0.00018929 & 0.00023565 \\
1_xvi & 0.0015134 & 0.00023565 & 0.0049948
\end{tabular}

Determinant $=6.88997 \mathrm{e}-010$ 
Normality Test

Appendix-E

Residual correlation matrix, C (3 x 3):
$\begin{array}{lll}1.0000 & 0.36516 & 0.59383\end{array}$
$\begin{array}{lll}0.36516 & 1.0000 & 0.24235\end{array}$
$\begin{array}{lll}0.59383 & 0.24235 & 1.0000\end{array}$

Eigenvalues of C:

$$
\begin{gathered}
0.389669 \\
0.790058 \\
1.82027
\end{gathered}
$$

The Doornik-Hansen test: Test for null hypothesis of normal distribution Chi-square $(6)=7.67642[0.2628]$

Forecasting for 5 Periods:

\section{Appendix-F}

For $95 \%$ confidence intervals, $\mathrm{z}(0.025)=1.96$

\begin{tabular}{|l|c|c|c|c|}
\hline Obs & 1_export & prediction & std. error & 95\% interval \\
\hline 2017 & undefined & 15.0082 & 0.0360610 & $(14.9376,15.0789)$ \\
\hline 2018 & undefined & 15.1548 & 0.0625141 & $(15.0323,15.2773)$ \\
\hline 2019 & undefined & 15.3121 & 0.0863231 & $(15.1429,15.4812)$ \\
\hline 2020 & undefined & 15.4637 & 0.109012 & $(15.2500,15.6773)$ \\
\hline 2021 & undefined & 15.6043 & 0.126999 & $(15.3554,15.8532)$ \\
\hline
\end{tabular}


Figures

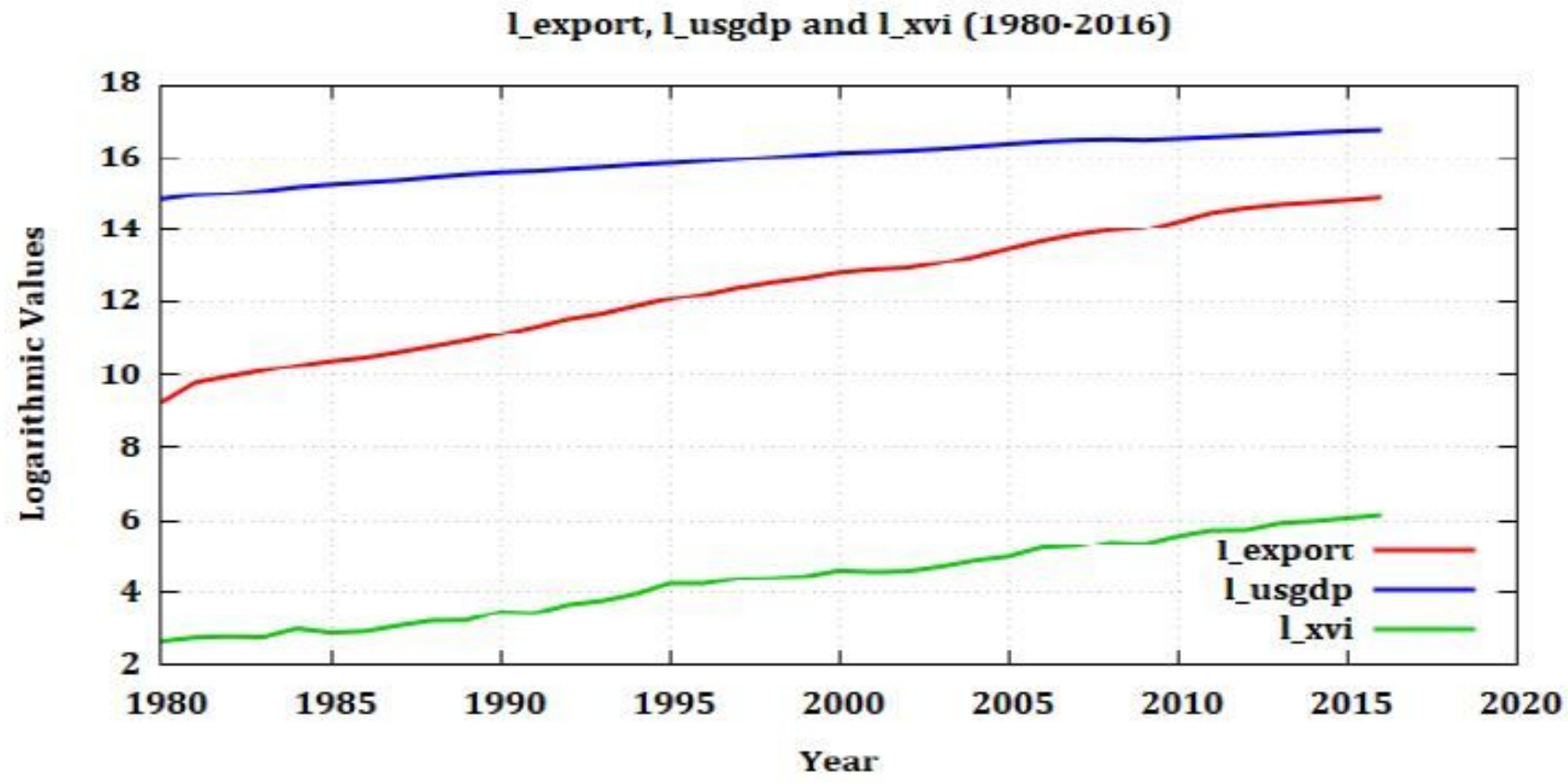

Figure 1

Graphical Plotting of I_export, I_usgdp, and I_xvi
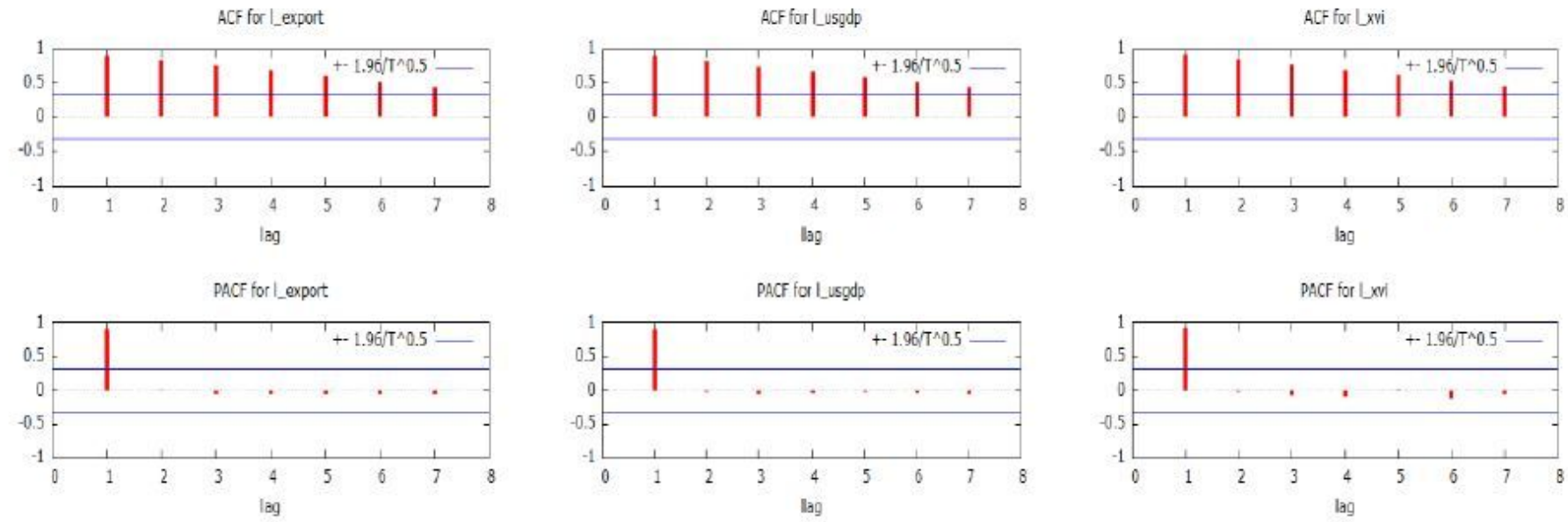

Figure 2

Correlograms of I_export, I_usgdp and I_xvi 


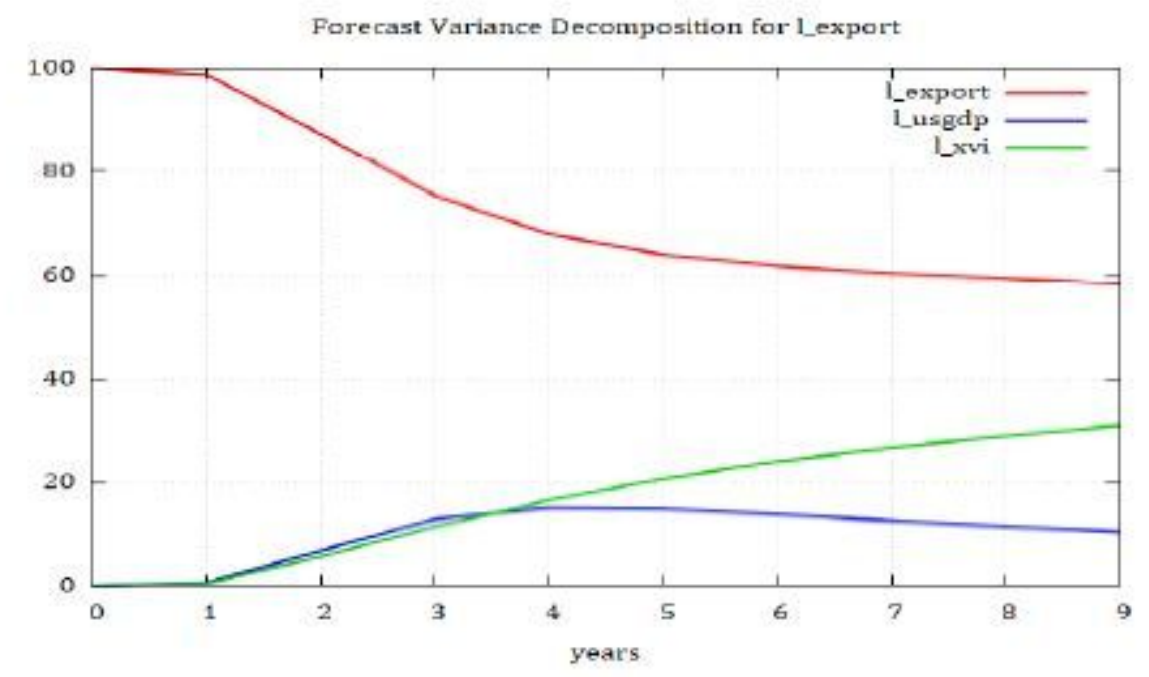

\section{Figure 3}

Forecast of Variance Decomposition for I_export
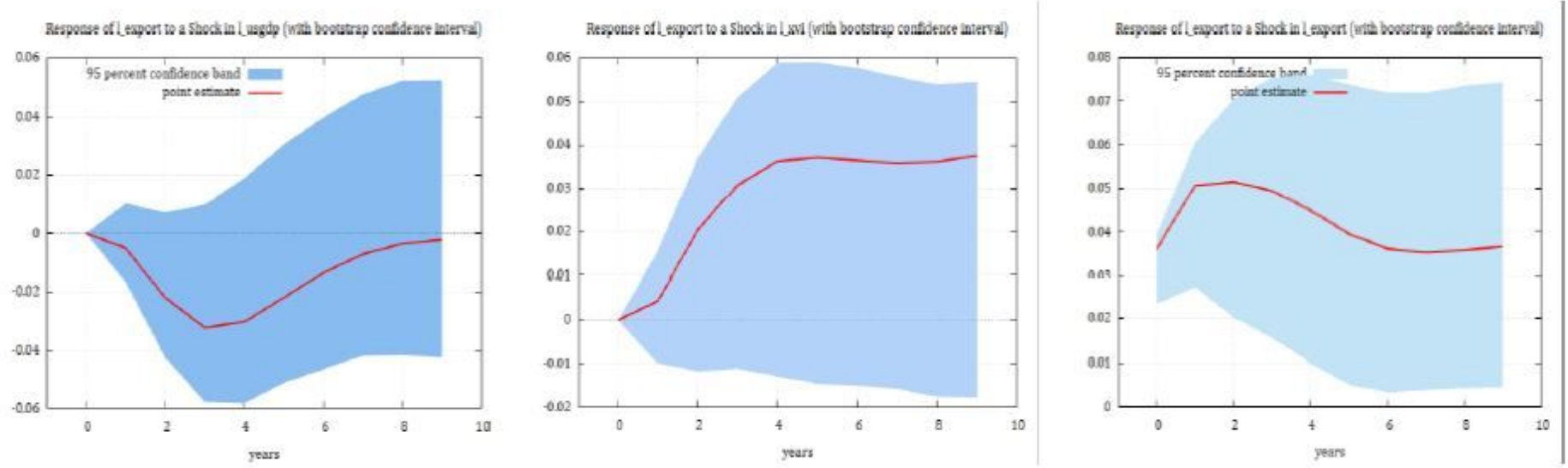

Figure 4

Impulse Response Functions of I_export (with 95\% Confidence Band) 


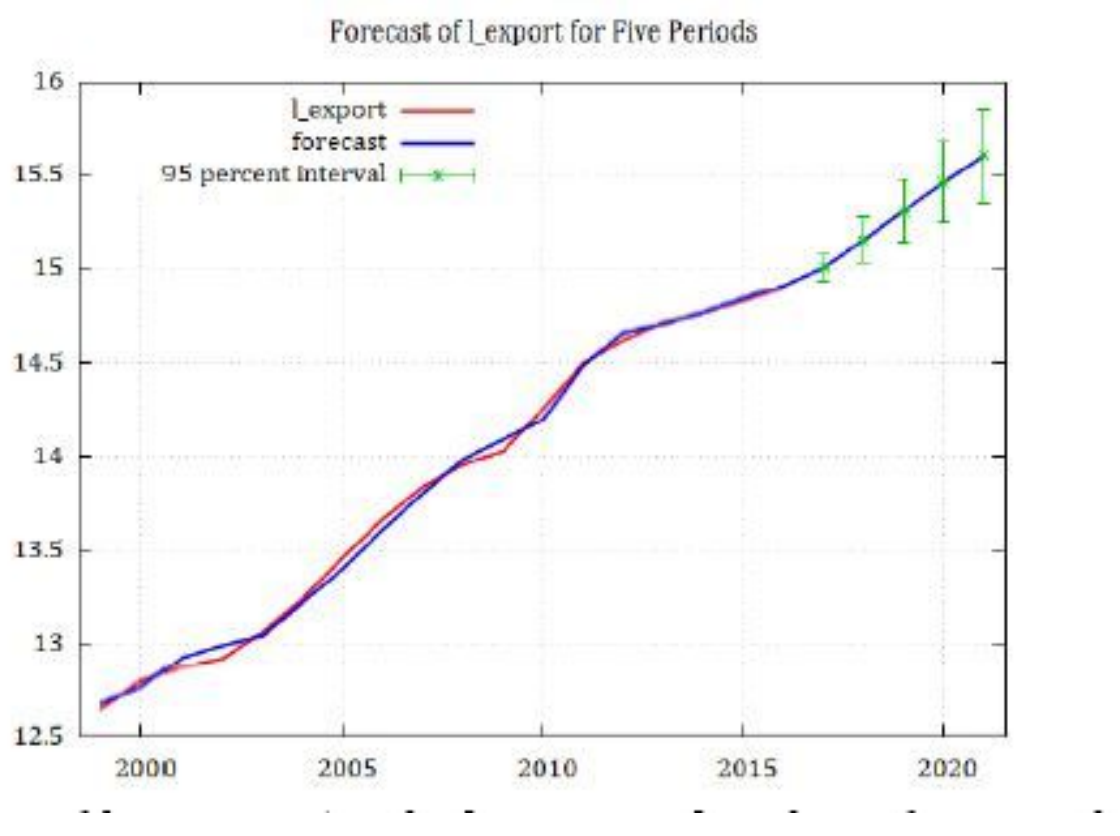

Figure 5

Forecast of I_export (Including Fitted Values for Pre-forecast Range)

\section{Supplementary Files}

This is a list of supplementary files associated with this preprint. Click to download.

- Acknowledgment.pdf 